In a heavily referenced keynote article, Peter H. Sand, former Secretary-General of the Convention on International Trade in Endangered Species of Wild Fauna and Flora (CITES), draws some disquieting conclusions about the future of the CITES agreement in regulating transnational trade in endangered species. "There are signs that CITES may indeed have reached its outer limits," he writes (p. 26). "Considering the treaty's focus on transnational trade, the advent of large free trade areas--aimed at the abolition of internal trade boundaries--is bound to diminish the future relevance of CITES-type border controls, unless new methods of regulation can be developed to cope with geopolitical changes of that order."

In an evaluation of the United Nations Development Programme (UNDP)--an "organization still in search of a role"--Poul Engberg-Pedersen and Claus Hvashfj Jfrgensen argue persuasively that the UNDP can be of best use building institutional skills at a local level. "Developing-country governments are quite willing to sign and ratify international environmental agreements, but are lacking in capacity for implementation at national level," they argue (p. 37). "Given the UNDP's centralized structure, its institutional presence in 130 countries, its close links with recipient governments, its multisectoral mandate, and its instruments of technical co-operation, we argue for a much stronger UNDP focus on capacity development assistance to the governments of developing countries."

In other insightful articles Lisa Jorgenson details the substantial challenges to environmental regulation of international waters; Leif E. Christoffersen profiles the International Union for Conservation of Nature and Natural Resources (now known simply as the World Conservation Union); Jacob Park warns about challenges facing the World Wildlife Fund for Nature.

If anything, I would like to see far more of these evaluations in future editions of the yearbook. Ideally, each treaty and organization listed would have a companion overview (though, admittedly, this would require a much greater commitment of resources from authors, funding sources, and Oxford University Press). In the meantime, however, previous yearbooks remain available (search the keywords "Green Globe Yearbook" at http://www.amazon.com for details) and contain evaluation articles on a wide variety of important topics. An index of those topics is available in the current volume.

In sum, the Green Globe Yearbook is a valuable resource and an important contribution to the global political dialog on environment and development--one that activists, policy makers, teachers and, yes, their students should have handy.

\title{
After the USSR. Ethnicity, Nationalism, and Politics in the Commonwealth of Independent States, by Anatoly M. Khazanov. Madison: University of Wisconsin Press. 1995, 310 pages.
}

\section{Reviewed by Pal Kolstö, Department of East European and Oriental Studies, University of Oslo}

Anatoly Khazanov worked as a senior researcher at the Soviet Institute of Ethnography and Anthropology in Moscow before he left for the West as a refusenik in 
1985. He is currently professor of anthropology at the University of Wisconsin-Madison and has retained a keen interest in the development of ethnopolitics in his former country of residence. The national revivals among the non-Russians, which were a major cause behind the fall of the Soviet state, started just after he had left, but thanks to the new political climate of perestroyka and post-perestroyka, Khazanov was soon able to pick up contact again with his old colleagues in Moscow. During the "stagnation" period the Institute of Ethnography and Anthropology was one of the ablest institutions of the Soviet Academy of Science, practically all Soviet anthropological expertise was concentrated there.

I therefore agree with the dust-cover advertisement that Khazanov's double background makes him uniquely qualified to analyse the ethnic aspects of perestroyka and post-perestroyka politics. He is able to combine the insider's intimacy with the subject matter with the outsider's detached analysis "from afar". I also believe that Khazanov has succeeded well in his endeavour. He does not rely on general impressions from his lifetime exposure to Soviet anthropology only, but has digested and refers to an impressive array of Soviet and post-Soviet anthropological studies. Also his reading of Western theoretical and comparative literature is extensive. (Note when the references are as frequent and as many as in Khazanov's book, the editorial convention used here for references is not ideal. The flow of the presentation is interrupted too often; sometimes one has to scan through more than one line of references before the narrative is resumed.)

The structure of Khazanov's book is, as it were, wedge-shaped, beginning in the thick end with a broad overview and gradually working towards an ever-narrower focus. The three first chapters deal with all-Union issues, during and after the collapse of the Soviet state. The fourth chapter is devoted to one region, Central Asia; the fifth, to one post-Soviet country, Kazakhstan; the sixth to an autonomous republic within the Russian Federation, Yakutia; and the seventh to one particular ethnic group, the Meskhetian Turks.

As a last-minute postscript Khazanov has added a chapter on the Chechen war, which was being fought ferociously while he was writing his book. This chapter, inevitably, is less scholarly than the others. Khazanov must rely on his general knowledge about Chechenia (which is good) and on media reports which he did not have a chance to verify. The emotional temperature in this chapter is very high. Khazanov finds the Russian decision to try to "solve" the Chechen problem by military means utterly incomprehensible, bordering on sheer idiocy. I tend to agree, but nevertheless believe that we should not look for the causes behind the war in Russian corridor politics only. The fear of a domino effect if Chechenia were allowed to go, probably unfounded but no less real for that, most certainly played a greater role than Khazanov is willing to grant. So did economic issues such as control over the important pipeline running though Grozny. Also Khazanov's conclusion that the war reflected Yeltsin's "general shift to the right" was probably premature. Today, the pendulum of Kremlin politics seems to have swung towards the liberal position again (but of course, with the still rather unpredictable and erratic nature of Russian politics, not only Khazanov's book but also this review may well be overtaken by events before it is read.)

The first three overview articles were sober and useful, but, as far as I could register, did not contain any really new insights or information. They are based on a modernist understanding of ethnicity; the book, in fact, is dedicated to the late Ernest Gellner. Khazanov regards the forces unleashed by uneven and differential modernisation in plural societies as a very important factor behind the ethnic revivals in the Soviet Union during perestroyka, and rightly so. At the same time, he avoids the pit-fall of determinism which 
a modernist interpretation may easily lead into, (and which, I believe, Gellner for one was guilty of). Khazanov's theory of ethnicity seems to me more flexible and less assertive than Gellner's. Khazanov admits that the ethnic explosion in the Soviet Union cannot be explained by modernization alone, also a number of other factors must be taken into consideration. He is inclined to think that the dynamics of ethnopolitics made the break-up of the Soviet Union inevitable (the determinist view), but recognizes that this view is speculative.

Following the latest trend in Soviet studies, Khazanov claims that the Soviet concept of ethnicity was primordialist "inasmuch as it was based on the notion of descent." In contemporary anthropological science "primordialism" is a four-letter word. Khazanov goes one step further in vilifying the Soviet approach to ethnicity by adding that "in many respects it was close to conceptions that dominated in Nazi Germany." Soviet thinking on ethnicity was to no small degree informed by the writings and thinking of Khazanov's colleagues and predecessors among the Moscow anthropologists and I think that his stricture is unfair to them. The writings of such Soviet coryphaei as Bromley, Kozlov and others were certainly much more sophisticated than the ramblings of Nazi ideology. Also, their understanding of ethnicity was not that far removed from much of what was produced in the West, in particular, what was being written on ethnic relations in the USSR. Indeed, in the 1970s and 1980s certain Western scholars accused Soviet anthropologists of not being "primordialist" enough. While not actually applying this word, they lambasted Bromley and his colleagues for writing in terms of "ethnic processes." Such concepts these Western scholars regarded as a cover for assimilatory policies (read: 'Russification'). The natural state of affairs, in their view, is when whoever is born a Ukrainian or a Latvian remains so throughout his/her life and begets children belonging to the same nationality.

Khazanov's book really came to life when he moved from macroanalysis to microanalysis. In the second half, he focuses on the Asian parts of the former Soviet Union, which clearly are the regions he knows best. Indeed, some elementary slips when he makes a foray into the European region may make one wonder about the depth of his knowledge about these republics. Inexplicably, he confuses the Dniepr and the Dniester rivers and talks about a "Pridnepr" secessionist republic in Moldova. By contrast, his understanding of Soviet Asian affairs is always thorough and deep--with the partial exception of economics. Khazanov claims, for instance, that "the subsidies that the center paid Central Asian republics were only partial compensation for the profits made from unequal exchange with them." This assertion goes against the grain of most Western research, and supporting references provide only two figures illustrating ethnodemographic change in Central Asia, with nothing about economics. My puzzlement remains.

To be sure, in every former Soviet republic today, including Russia and the relatively prosperous Baltics, numerous nationalists are trying to prove that their republic was economically more exploited by the Communists than all the others. I agree with Khazanov that the communist system was oppressive, even to the point of being (as he claims) totalitarian. Also, the Soviet system was certainly irrational in economic terms, utterly ineffective, and with disastrous ecological consequences, not least in Central Asia. So far, however, I have not found any really convincing evidence that the Brezhnevite system, reprehensible as it was, was directed with particular animus against any one region or ethnic group. If Central Asia was economically exploited by the centre, the new, independence countries in this region should have been better able to solve their economic 
and ecological problems today, now that the oppressor is gone. Khazanov, however, implicitly acknowledges that this certainly is not the case.

As one moves through the book toward the sharp edge of the analysis it becomes increasingly fascinating to read. The two best chapters are the ones on Yakutia and the Meskhetian Turks. These case studies are based on very thorough research, which is presented in great detail without ever becoming tedious. The empirical evidence is analysed with sophistication and clearly shows the fruitfulness of the author's theoretical approach.

The two subchapters on Yakutia, on political nationalism and cultural nationalism, complement each other nicely. Once again, however, I felt that Khazanov somewhat underplays the economic factor. As the rich deposits of gold and diamonds in Yakutia certainly are important factors explaining why local Russians also tend to support the campaign for Yakutian sovereignty, a third subchapter on economic nationalism in Yakutia would not have been out of place.

To sum up: Khazanov has written a very good and authoritative book, at times even outstanding. The few critical remarks made above do not detract from this conclusion.

\section{Global Accord: Environmental Challenges and International Responses, Nazli Choucri, editor. 1995. Cambridge, MA: MIT Press. xxiv, 562 pp.}

\section{Reviewed by Aaron T. Wolf, Department of Geography, University of Alabama}

The major hurdle in addressing issues of global change is that they stretch the limits both of scientific forecasting and of institutional capacity to handle uncertainty. Results from global forecasting models have immense uncertainties, whereas institutional planning horizons are generally only as distant as the next election. As the time scale of study increases, scientific uncertainty drops, but so does the ability of institutions to address the problems.

Stepping squarely into the breach of this frictional intersection between science and policy is Global Accord: Environmental Challenges and International Responses, edited by MIT professor Nazli Choucri. This collection of 15 chapters makes explicit each of the sets of relations that make global change such a difficult topic to address--relationships between science and policy, nature and humanity, growth and preservation, moredeveloped and less-developed nations, and even between present and future generations.

In fact, the entire book is about relationships: most of its sections are even titled in pairs ("Actors and Processes," "Economics and Law," "Institutions and Systems"). Its fundamental premise is that whereas in the past some leeway has existed for many of these relationships to be skewed one way or the other, all of these actors and their interests (including those of nature) are now so intertwined that, in the words of Maurice Strong in his foreword, "effective international responses can be achieved only on the basis of cooperation among nations, and effective cooperation must be based on common interests." 